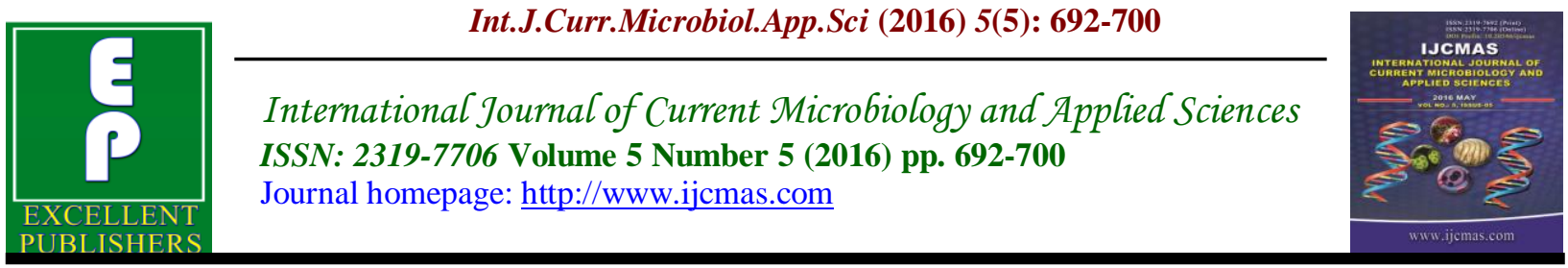

Original Research Article

http://dx.doi.org/10.20546/ijcmas.2016.505.070

\title{
Antimicrobial Potential of Some Local Spices Used in Ghanaian Meals
}

\author{
Samuel N. Osei-Djarbeng ${ }^{1 *}$, Amina Abubakari ${ }^{2}$, Charles Ayensu Okai ${ }^{2}$, \\ Ruth Boateng ${ }^{3}$ and George A. Pesewu ${ }^{4}$ \\ ${ }^{1}$ Department of Pharmaceutical Sciences, Faculty of Health Sciences, Kumasi Polytechnic, \\ P.O. Box 854, Kumasi-Ghana \\ ${ }^{2}$ Department of Laboratory Technology, Faculty of Health Sciences, Kumasi Polytechnic, \\ P.O. Box 854, Kumasi-Ghana \\ ${ }^{3}$ Department of Hotel, Catering and Institutional Management, Faculty of Applied Sciences, \\ Kumasi Polytechnic, P.O. Box 854, Kumasi-Ghana \\ ${ }^{4}$ Department of Medical Laboratory Sciences (MEDLAB), School of Allied Health Sciences, \\ College of Health Sciences, University of Ghana, P. O. Box KB 143, Korle-Bu, \\ Accra, Ghana, W/A \\ *Corresponding author
}

\begin{tabular}{|c|c|}
\hline & A B S T R A C T \\
\hline & Spices are used all over the world in preparation of food and sometimes beverages. \\
\hline Keywords & $\begin{array}{l}\text { The principal reason for its use is to add flavour to the food. Additionally some } \\
\text { spices are used for preservation purposes and sometimes to add colour. The aim of }\end{array}$ \\
\hline $\begin{array}{l}\text { Spices, } \\
\text { garlic, } \\
\text { onion, } \\
\text { nutmeg, } \\
\text { pepper, }\end{array}$ & $\begin{array}{l}\text { the present study is to investigate the potential antimicrobial properties of common } \\
\text { spices (onion, ginger, garlic, nutmeg and pepper) used in the Ghanaian dish; } \\
\text { employing the agar well diffusion and the micro-broth dilution methods. Garlic } \\
\text { exhibited the most potent antimicrobial activity against the microbes used in the } \\
\text { study namely; Staphylococcus aureus, Bacillus subtilis, Klebsiella pneumoniae }\end{array}$ \\
\hline $\begin{array}{l}\text { Ginger, } \\
\text { antimicrobial. }\end{array}$ & $\begin{array}{l}\text { Escherichia coli and Candida albicans. Ginger also showed a very good } \\
\text { antimicrobial activity. The other spices also exhibited some amount activity. Garlic }\end{array}$ \\
\hline Article Info & gave MIC of $0.25-0.5 \mathrm{mg} / \mathrm{ml}$; and ginger $1-2 \mathrm{mg} / \mathrm{ml}$. The minimum bactericidal \\
\hline $\begin{array}{l}\text { Accepted: } \\
18 \text { April } 2016 \\
\text { Available Online: } \\
10 \text { May } 2016\end{array}$ & $\begin{array}{l}\text { concentrations (MBCs) of garlic ranged from } 1-2 \mathrm{mg} / \mathrm{ml} \text { indicating that garlic is } \\
\text { likely to be bactericidal rather than bacteriostatic in nature. These spices with } \\
\text { antimicrobial potency may act as prophylactic antimicrobials which may offer } \\
\text { protection against some infections caused by the susceptible microbes. The study } \\
\text { has shown that some spices used in preparation of the Ghanaian meals have potent } \\
\text { in vitro antimicrobial activity. }\end{array}$ \\
\hline
\end{tabular}

\section{Introduction}

Spices have, for centuries, been used in food preparation as flavouring agents, preservatives and colourant (Scully, 1995); their use have sometimes been linked to medicine, religion, tradition and even magic.
They are normally obtained as dried seeds, fruits, roots or bark. The use of spices and its trade dates back to pre-historic times. Countries in Asia, particularly India and China are well noted for their regular use of 
spices in cuisine. In Ghana and many other African countries, spices are used in preparation of most of the household cookery and foods sold at restaurants and food joints. The most common spices used include onion, pepper, ginger, nutmeg and garlic.

Plants have served therapeutic purposes to mankind and animals for centuries thereby making an invaluable contribution to the healthcare needs of man. Many plants serving medicinal purposes have been investigated for various pharmacological activities including anti-microbial. And in some cases the active compound(s) responsible for the activities has/have been isolated and the chemical structures, elucidated. Scientists continue to do bioprospecting on plants with the aim of getting lead compounds that can help ameliorate the sufferings of man. Different groups of plants are targeted by different researchers for different therapeutic purposes. Research into plants with potential antimicrobial activities are on the ascendency, possibly, as a result of development of resistant strains of various microbes against the existing antimicrobials. This is coupled with the fact that for some years now no new antimicrobial agents have been developed to help combat the resistant strains of microbes. Our continuous search for plants that can help mankind prevent or fight off infectious microbes has drawn our attention to some local spices employed in the Ghanaian meals. The aim is to investigate the potential antimicrobial activities of spices such as garlic, ginger, nutmeg, onion and pepper.

Garlic, scientifically known as Allium sativum, belongs to the plant family Liliacea. It is found mostly among the people of China, North Africa (Egypt), Europe and Mexico; it is believed to have originated from Asia (Esminger, 1994). It contains sulphur compounds such as allicin (diallyl-dithiosulfinate), diallyl disulphide (DDS), S-allylcysteine (SAC) and diallyl trisulfide (DTS) (McRae, 2005; Lanzotti et al., 2012). The sulphur compounds and their break down products are responsible for the characteristic smell of garlic. Garlic is claimed to have several functional and pharmacologic activities. It is used in management of several microbial infections; as an antibacterial and antifungal (Ogita et al., 2006), antiviral and anti-parasitic (Ankri and Mirelman, 1999). Additionally the plant is claimed to have anti-hypertensive effect (Nwokocha et al., 2011).

Ginger (Zingiber officinale) belonging to the family Zingiberaceae, is found growing in South-eastern Asia, China, Japan, Latin America, Africa and many other places (Hasan et al., 2012). The plant contains volatile oils, and non-volatile pungent components, oleoresin (Zick et al., 2008). Compounds identified in ginger include gingerol, shogaol, zingerone, paradol, gingerenone A, zerumbone, vallinoids, galanals A and B. Ginger is reputed to have antimicrobial activities (Bellik, 2014), antiinflammatory activity (Sharma et al., 1994), anti-tumour activity (Ling, 2010).

Nutmeg (Myristica fragrans) is a member of the plant family Myristicaceae. It is believed to be a native of Banda Islands of Eastern Indonesia. It is used as a flavour in many dishes, usually in ground or grated form. It contains essential oils such as d-camphene, d-pinene, limonene, d-borned, l-terpineol, geraniol, sarfrol and myristicine (Maya et al., 2004). The oils are used in making toothpaste, cough syrups and other medicines to treat disorders related to the nervous and digestive systems. Nutmeg also contains phenolic anthocyanin pigment (Sonavane et al., 2004) found to exhibit 
antioxidant and antimicrobial activities against some microorganisms (Gupta et al., 2013).

Onion (Allium cepa) belongs to the same plant family, Liliaceae, as garlic. They are cultivated and used around the world as food item which is served cooked as a vegetable or part of a prepared savoury dish but can also be eaten raw or used for other variety of dishes. The major compounds presented in onion include dipropyl disulfide and dipropyl trisulfide (Kim et al., 2004).

Pepper (Capsicum spp) belongs to the family Solanaceae. It has variety of common names depending on where it comes from and the type. Capsaicin is an alkaloidal compound found in peppers which are responsible for their characteristic hot taste as well as it pungency. The level of hotness depends on the concentration of capsaicin in the fruit (Canton-Flick et al., 2008). Pepper is reported to have many therapeutic activities including anti-carcinogenic, antioxidant, anti-mutagenic, immunosuppressive, hypocholesterolaemic, and bacterial growth inhibition effects (Grubben and El Tahir, 2004). Chili pepper is used to ease digestion, stimulate the gut, combat constipation, and relieve pain in the field of traditional Medicine (Patwardhan et al., 2010). Peppers are also good sources of nutrients Vitamins A, B6, and K, calcium, iron, zinc, and fibre.

\section{Materials and Methods}

\section{Spices Used}

Samples of the spices used in the study namely garlic (Allium sativa), ginger (Zingiber officinale), nutmeg (Myristica fragrans), onion (Allium cepa) and pepper (Capsicum annuum) commonly called Guinea spice or cayenne pepper, were purchase from the Asafo Market, a local market in Kumasi, Ghana. They were identified by experts.

\section{Extraction of Plant Materials}

The spices samples were each cleaned with water and sun-dried for three days. The outer covering of the garlic and onion were removed. All the samples were chopped into pieces and further dried in the sun for additional two days. Each was milled and extracted with $96 \%$ ethanol at room temperature using cold maceration method for 48 hours (h). Each sample was filtered through a sterile muslin cloth, and the solvent allowed to evaporate in each case.

\section{Micro-organisms Used}

Micro-organisms used in the study consisted of both Gram-positive and Gram-negative bacteria and a clinical isolate of the yeastlike fungus Candida albicans. The Grampositives were Staphylococcus aureus (ATCC 25923), Bacillus subtilis (NCTC 10073) and the Gram-negatives included Klebsiella pneumonia (ATCC 70063) and Escherichia coli (ATCC 25922).

\section{Antimicrobial Assay}

The agar well diffusion method (OseiDjarbeng et al., 2014) was used in the assay. Wells were punched on the surface of Nutrient agar plates seeded with $100 \mu \mathrm{l}$ of an overnight broth suspension of microorganism (bacteria or fungi) containing 106 $\mathrm{cfu} / \mathrm{ml}$ of the organism. Different plates were prepared for each organism. Cork borer number three with a diameter of $6 \mathrm{~mm}$ was used to make 'wells' on the agar. One hundred microlitres $(100 \mu \mathrm{l})$ each of the spice extract, at a concentration of 10 $\mathrm{mg} / \mathrm{ml}$, was introduced into a corresponding labelled well in the agar. The negative control used was $10 \%$ methanol in sterile water which was used to reconstitute the 
extracts; and the positive controls were 100 $\mu \mathrm{g} / \mathrm{ml}$ Gentamicin (G) and Tetracycline (T) $[100 \mu \mathrm{g} / \mathrm{ml}]$ against the bacteria; and 100 $\mu \mathrm{g} / \mathrm{ml}$ Clotrimazole (C) against C. albicans. The plates were allowed to be on the laboratory bench for about an hour (h) before incubating at $37{ }^{\circ} \mathrm{C}$ for $24 \mathrm{~h}$. The antimicrobial activity was evaluated by taking measurements of the diameters of the zones of inhibition around each well.

\section{Determination of Minimum Inhibitory Concentration}

The Micro-broth dilution method using 96well plates (Eloff, 1999) which is suitable for determination of Minimum Inhibitory Concentration (MIC) was used to determine the MICs of the samples. Each sample was serially diluted two-fold with Nutrient broth to give a dilution range of $4000 \mu \mathrm{g} / \mathrm{ml}$ $(4 \mathrm{mg} / \mathrm{ml})$ to approximately $8 \mu \mathrm{g} / \mathrm{ml}$ in 96 well-plates. One hundred microlitres $(100 \mu \mathrm{l})$ of overnight broth culture of organisms containing $105 \mathrm{cfu} / \mathrm{ml}$ was added to each well, and incubated at $37^{\circ} \mathrm{C}$ for $18 \mathrm{~h}$.

Control wells did not contain the test extracts, and the vehicle control wells contained scalar dilutions of $10 \%$ methanol. Serial dilution each of Clotrimazole, Gentamicin and Tetracycline (from 1000 to approximately $1 \mu \mathrm{g} / \mathrm{mL}$ ) were used as the positive control. The plates were examined for growth after $18 \mathrm{~h}$. The MIC values were confirmed by addition of $40 \mu \mathrm{L}$ of 0.2 $\mathrm{mg} / \mathrm{mL} \quad$ concentration of $\rho$-iodonitrotetrazolium (INT) violet to each well, incubated at $37^{\circ} \mathrm{C}$ for further $30 \mathrm{~min}$, and observed for colour change from purple to pale yellow.

\section{Determination of Minimum Bactericidal Concentration (MBC)}

The MBC or MFC (minimum fungicidal concentration) was determined by placing
$10 \mu \mathrm{l}$ of the content of the wells from the afore-mentioned MIC plates onto a perfectly dried agar. This was done before addition of the INT to the wells for the MIC. The plates were then incubated at $37^{\circ} \mathrm{C}$ for $18-24 \mathrm{~h}$. The least concentration of the extract that gave no growth after incubation was taken to be the MBC.

\section{Statistical Analysis}

The experiments were run in triplicates; and the results were expressed as Mean \pm SD (standard deviation) data using Microsoft Excel (Windows 2007).

\section{Results and Discussion}

Garlic extract showed the highest antimicrobial activity among the samples used in the study. This was followed by ginger. The other spices also showed some level of antimicrobial activity (Table 1). Previous studies have shown that garlic has a good antimicrobial activity against many microbes including Methicillin-resistance Staphylococcus aureus (Cutler and Wilson, 2004).

Ginger has also exhibited antimicrobial activity against both Gram-negative and Gram-positive bacteria in other studies (Park et al., 2008; Karuppiah and Rajaram, 2012). Similarly nutmeg has also shown antimicrobial potency in a previous study (Gupta et al., 2013). Onion, though belongs to the same family of plants as garlic, did not show the similar antimicrobial activity as garlic; it exhibited a lower antimicrobial activity relative to garlic. From Table 1, pepper showed a moderate antimicrobial activity against the organisms used in the study. 
Table.1 Antimicrobial Activities of Some Spices (and Controls) Expressed As Diameter of Zones of Inhibition $(\mathrm{N}=3)$.

\begin{tabular}{|c|c|c|c|c|c|c|c|c|}
\hline \multirow[b]{3}{*}{ Micro-organisms } & \multicolumn{8}{|c|}{ Average Diameter of Zones of Inhibition (mm) } \\
\hline & \multicolumn{5}{|c|}{ Spices } & \multicolumn{3}{|c|}{ Controls } \\
\hline & Gar & Gin & Nut & Oni & Pep & $\mathbf{G}$ & $\mathbf{T}$ & $\mathbf{C}$ \\
\hline $\begin{array}{c}\text { Staphylococcus } \\
\text { aureus }\end{array}$ & $20 \pm 1$ & $16 \pm 0.5$ & $13 \pm 0.5$ & $12 \pm 1$ & $12 \pm 0.5$ & $24 \pm 1$ & $23 \pm 0.5$ & - \\
\hline Bacillus subtilis & $20 \pm 1$ & $17 \pm 0.0$ & $13 \pm 1$ & $12 \pm 1$ & $11 \pm 0.5$ & $26 \pm 1$ & $24 \pm 0.5$ & - \\
\hline Escherichia coli & $\begin{array}{c}21 \pm 0 \\
5\end{array}$ & $15 \pm 0.5$ & $11 \pm 0.5$ & $10 \pm 1$ & $11 \pm 0.5$ & $23 \pm 0.5$ & $22 \pm 0.5$ & - \\
\hline Klebsiella pneumonia & $\begin{array}{c}19 \pm 0 \\
5\end{array}$ & $16 \pm 0.5$ & $11 \pm 0.5$ & $09 \pm 1$ & $11 \pm 1$ & $24 \pm 1$ & $22 \pm$ & - \\
\hline Candida albicans & $16 \pm 1$ & $15 \pm 0.5$ & $13 \pm 1.0$ & $10 \pm 0.5$ & $10 \pm 1$ & - & - & $23 \pm 1$ \\
\hline
\end{tabular}

Key: Gar - garlic; Gin - ginger; Nut - nutmeg; Oni - onion; Pep - pepper. G - Gentamycin; T - Tetracycline; C Clotrimazole; - - Not tested.

The bacteria used in the study are among the very pathogenic ones classified under the multi-drug resistant (MDR) bacteria. Some strains of these bacteria are resistant to most groups of antimicrobial agents including the penicillins, cephalosporins and aminoglycosides. For garlic and ginger to exert potent antimicrobial activity against these organisms is good news. These spices are consumed on regular basis by many people without the intention of using it for its antimicrobial purposes. These agents, inadvertently, may confer their antimicrobial activity on the consumer, and help prevent or combat infections caused by susceptible micro-organisms. Indiscriminate use of antimicrobial agents have contributed significantly to the failure of most antimicrobials to fight infections. However, in the case of the potential antimicrobial activities of spices, development of resistance may be remote in spite of their regular use. This is because the observed therapeutic activity of the species is not attributed to only one compound; several compounds present in the plants work together, perhaps synergistically, to give the activity. For example the antibacterial activity of garlic has been attributed to allicin, thiosulfinates and their transformational products, and other essential oils present in the plant (Kyung, 2012; Benkablia, 2004). Antimicrobial activity of ginger has also been attributed to caryophyllene, zingiberene, gingerol, gingerone, dihydrogingerone, dehydrozingerone and dehydroshogoal (El-Baroty et al., 2010) all present in the plant. Additionally, nutmeg contains myristic acid, trimyristin, and lignans (erythroaustrobailignan-6, meso-dihydroguaiaretic acid and nectandrin-B) which have all shown antimicrobial activity (Cho et al., 2007; Narasimhan and Dhake, 2006). Pepper and onion similarly contain many compounds that each has an antimicrobial activity. In a typical local Ghanaian dish, it is not uncommon to find at least two of the spices under study. The numerous antimicrobial compounds present in each may act together to offer protection against infection.

The results for the minimum inhibitory concentrations (MICs), which refers to the least amount of the extract (antimicrobial 
agent) required to inhibit the in vitro growth of bacteria or fungi as detected by the unaided eye, is shown in Table 2. Table 3 also shows that for the minimum bactericidal concentrations (MBCs), which depicts the lowest amount of the antimicrobial agent required to destroy $99.9 \%$ of the inoculum of the microorganisms (CLSI, 1998). Where the MBC value is more than four times that of the MIC for a particular antimicrobial agent, that agent is regarded as bacteriostatic. In other words, bacteriostatic activity can be expressed as a ratio of MBC to MIC greater than four (Pankey and Sabath, 2004). Garlic gave MIC of $0.5 \mathrm{mg} / \mathrm{ml}$ against $S$. aureus (Table 2) and MBC of $1.0 \mathrm{mg} / \mathrm{ml}$ against the same microbe (Table 3). The ratio of $\mathrm{MBC}$ to MIC of garlic for this organism is two, indicating that garlic is bactericidal against S. aureus.

Table.2 MICs of the Spices and Controls

\begin{tabular}{|c|c|c|c|c|c|c|c|c|}
\hline \multirow[b]{3}{*}{ Micro-organisms } & \multicolumn{8}{|c|}{ MIC } \\
\hline & \multicolumn{5}{|c|}{ Spices $(\mathrm{mg} / \mathrm{ml})$} & \multicolumn{3}{|c|}{ Controls $(\mu \mathrm{g} / \mathrm{ml})$} \\
\hline & Gar & Gin & Nut & Oni & Pep & $\mathbf{G}$ & $\mathbf{T}$ & $\mathbf{C}$ \\
\hline Staphylococcus aureus & 0.5 & 1 & 2 & 4 & 2 & 16 & 32 & - \\
\hline Bacillus subtilis & 0.25 & 1 & 2 & 2 & 4 & 16 & 32 & - \\
\hline Escherichia coli & 0.5 & 2 & 4 & 2 & 2 & 32 & 32 & - \\
\hline Klebsiella pneumonia & 0.5 & 1 & 4 & 4 & 2 & 16 & 62 & - \\
\hline Candida albicans & 0.25 & 1 & 2 & 4 & 4 & - & - & 32 \\
\hline
\end{tabular}

Key: As under Table 1.

Table.3 MBCs (MFC) of the spices and controls

\begin{tabular}{cccccc|ccc}
\hline & \multicolumn{9}{c}{ MBC } \\
\cline { 2 - 9 } Micro-organisms & Gar & Gin & Nut & Oni & Pep & G & T & C \\
\cline { 2 - 9 } & 1 & $\phi$ & $\phi$ & $\phi$ & $\phi$ & 64 & 250 & - \\
\hline Staphylococcus aureus & 1 & 2 & $\phi$ & $\phi$ & $\phi$ & 64 & 250 & - \\
\hline Bacillus subtilis & 2 & $\phi$ & $\phi$ & $\phi$ & $\phi$ & 128 & 250 & - \\
\hline Escherichia coli & 2 & $\phi$ & $\phi$ & $\phi$ & $\phi$ & 64 & 250 & - \\
\hline Klebsiella pneumonia & 2 & 4 & $\phi$ & $\phi$ & $\phi$ & - & - & 128 \\
\hline Candida albicans & 2 &
\end{tabular}

Key: As under Table $1 ; \phi$ - MBC values greater than $4 \mathrm{mg} / \mathrm{ml}$

In using the micro-broth dilution method for determination of MIC endpoint, the naked eye can help distinguish between wells in the micro-titre plates that are turbid and those that are clear. There are, however, many colourimetric methods centred on the use of dye reagents to help differentiate growth in the wells. There are also devices that can facilitate reading and recording of microdilution tests (Balouiri et al., 2016). In this study a tetrazolium dye, pIodonitrotetrazolium Violet (INT) was used to confirm the MIC endpoint. The use of the INT is based on a colourimetric reaction involving the transfer of electrons from NADH. Bacteria and fungi produce threonine dehydrogenase (TDH), that catalyses the NAD-dependent oxidation of 
threonine to form 2-amino-3-ketobutyrate and NADH. During active growth an electron is transferred from NADH (which is colourless) to INT resulting in formation of a purple coloured formazan dye (Masoko et $a l ., 2007)$. Thus clear zones indicate growth inhibition whilst purple colouration indicates active growth. This reaction offered a simple test to verify the MIC results.

In conclusion, Species are common in the meals of many people all over the world. Some of these spices that are commonly used may have therapeutic activities. The present study has shown that many of the local spices used in the Ghanaian meal have in vitro antimicrobial activity. If this in vitro activity has the same in vivo action in man then that would mean consumption of the spices used in the study, especially garlic and ginger, would offer antimicrobial prophylaxis when used. It has been shown that garlic, ginger, nutmeg, pepper and onion have antimicrobial activities against some microbes, and as such may help in preservation.

\section{References}

Ankri, S., Mirelman, D. 1999. Antimicrobial properties of allicin from garlic. Microbes Infect., 2: 125-129.

Balouiri, M., Sadiki, M., Ibnsouda, B. 2016. Methods for in vitro evaluating antimicrobial activity: A review. $J$. Pharma. Analysis, 6(2): 71-79.

Bellik, Y. 2014. Total antioxidant activity and antimicrobial potency of the essential oil and oleoresin of Zingiber officinale Roscoe. Asian Pac. J. Trop. Dis., 4: 40-44.

Benkablia, N. 2004. Antimicrobial properties of Allium species. Food Sci. Technol., 37(2): 263-268.

Canton-Flick, A., Balam-Uc, E., Jabın Bello-Bello, J., Lecona-Guzman, C.,
Solıs-Marroquin, D., Aviles-Vinas, S., Gomez-Uc, E., Lopez-Puc, G., Santana-Buzzy. 2008. Capsaicinoids content in Habanero pepper (Capsicum chinense Jacq.): Hottest known cultivars. HortSci., 43(5): 1344-1349.

Cho, J.Y., Choi, G.J., Son, S.W., Jang, K.S., Lim, H.K., Lee, S.O., Sung, N.D., Cho, K.Y., Kim, J.C. 2007. Isolation and antifungal activity of lignans from Myristica fragrans against various plant pathogenic fungi. Pest Management Sci., 63(9): 935-940.

CLSI. 1998. Methods for Determining Bactericidal Activity of Antimicrobial Agents. Approved Guideline, CLSI document M26-A. Clinical and Laboratory Standards Institute, 950 West Valley Roadn Suite 2500, Wayne, Pennsylvania 19087, USA.

Cutler, R.R., Wilson, P. 2004. Antibacterial activity of a new, stable, aqueous extract of allicin against methicillinresistant Staphylococcus aureus. Br. J. Biomed. Sci., 61(2): 71-74.

Deepa, N., Kaur, C., George, B., Singh, B., Kapoor, H.C. 2007. Antioxidant constituents in some sweet pepper (Capsicum annuum L.) genotypes during maturity. LWT- Food Sci. Technol., 40(1):121 -129.

El-Baroty, G.S., Abd El-Baky, H.H., Farag, R.S., Saleh, M.A. 2010. Characterization of antioxidant and antimicrobial compounds of cinnamon and ginger essential oils. African J. Biochem. Res., 4(6): 167174.

Eloff, J.N. 1999. The Antibacterial Activity of 27 South African Members of the Combretaceae. South African J. Sci., 95: 148-152.

Ensminger, A.H. 1994. Foods \& Nutrition Encyclopedia (1). CRC Press, 750. 
Gupta, A.D., Bansal, V.K., Babu, V., Maithil, N. 2013. Chemistry, antioxidant and antimicrobial potential of nutmeg (Myristica fragrans Houtt). J. Genetic Engineering and Biotechnol., 11(1): 25-31.

Hasan, H.A., Rasheed, R.A.M., Abd Razik, B.M., Rasool, H.B.A. 2012. Chemical Composition and Antimicrobial Activity of the Crude Extracts Isolated from Zingiber officinale by Different Solvents. Pharma. Anal. Acta., 3: 184.

Karuppiah, P., Rajaram, S. 2012. Antibacterial effect of Allium sativum cloves and Zingiber officinale rhizomes against multiple-drug resistant clinical pathogens. Asian Pac. J. Trop. Biomed., 2(8): 597-601.

Kim, J.W., Huh, J.E., Kyung, S.H., Kyung, K.H. 2004. Antimicrobial activity of alk(en)yl sulfides found in essential oils of garlic and onion. Food Sci. Biotechnol., 13: 235-239.

Kyung, K.H. 2012. Antimicrobial properties of Allium species. Curr. Opinions in Biotechnol., 23(2): 142-147.

Kyung, K.H., Lee, Y.C. 2001. Antimicrobial activities of sulfur compounds derived from S-alk(en)yl-1-cysteine sulfoxides in Allium and Brassica. Food Rev. Int., 17:183-198.

Lanzotti, V., Barile, E., Antignani, V., Bonanomi, G., Scala, F. 2012. Antifungal saponins from bulbs of garlic, Allium sativum L. var. Voghiera. Phytochem., 78: 126-134.

Ling, H., Yang, H., Tan, S.H., Chui, W.K., Chew, E.H. 2010. 6-Shogaol, an active constituent of ginger, inhibits breast cancer cell invasion by reducing matrix metalloproteinase- 9 expression via blockade of nuclear factor $-\kappa \mathrm{B}$ activation. $\mathrm{Br}$. J. Pharm., 161: 1763-1777.
Masoko, P., Picard, J., Eloff, J.N. 2007. The Antifungal Activity of Twenty-four South African Combretum species (Combretaceae). S. Afr. J. Bot., 73: 173-183.

Maya, K.M., Zachariah, T.J., Krishnamoorthy, B. 2004. Chemical composition of essential oil of nutmeg (Myristica fragrans Houtt.) accessions. J. Spices Aromatic Crops, 13: 135-139.

McRae, M.P. 1994. A review of studies of garlic (Allium sativum) on serum lipids and blood pressure before and after 1994: does the amount of allicin released from garlic powder tablets play a role. J. Chiropr. Med., 4: 8290.

Narasimhan, B., Dhake, A.S. 2006. Antimicrobial principles from Myristica fragrans seed. J. Med. Food, 9(3): 395-399.

Nwokocha, C.R., Ozolua, R.I., Owu, D.U., Nwokocha, M.I., Ugwu, A.C. 2011. Antihypertensive properties of Allium sativum (garlic) on normotensive and two kidney one clip hypertensive rats. Niger J. Physiol. Sci., 26: 213-218.

Ogita, A., Fujita, K., Taniguchi, M., Tanaka, T. 2006. Enhancement of the fungicidal activity of amphotericin B by allicin, an allyl-sulfur compound from garlic, against the yeast Saccharomyces cerevisiae as a model system. Planta Med., 72:1247-1250.

Osei-Djarbeng, S.N., Amonoo-Neizer, J., Boadi, P., Opoku, P.N.A., OseiAsante, S. 2014. Comparative Antimicrobial Activities of Different Solvent Extracts and a Refreshing Drink (Sobolo) made from Hibiscus sabdariffa Linn. Int. J. Herbal Med., 2(3): 1-4.

Pankey, G.A., Sabath, L.D. 2004. Clinical Relevance of Bacteriostatic versus Bactericidal Mechanisms of Action in 
the Treatment of Gram-Positive Bacterial Infections. Clin. Infect. Dis., 38(6): 864-870.

Park, M., Bae, J., Lee, D. 2008. Antibacterial activity of gingerol isolated from ginger rhizome against periodontal bacteria. Phytother. Res., 22: 1446-1449.

Patwardhan, A.M., Armen, N.A., Ruparel, N.B., Diogenes, A., Weintraub, S.T., Uhlson, C., Murphy, R.C., Hargreaves, K.M. 2010. Heat generates oxidized linoleic acid metabolites that activate TRPV1 and produce pain in rodents. J. Clin. Invest., 126(5): 1617-1626.

Scully, T. 1995. The art of cookery in the Middle Ages. Ipswich: Boydell Press. 84-86.
Sharma, J.N., Srivastava, K.C., Gan, E.K. 1994. Suppressive effects of eugenol and ginger oil on arthritic rats. Pharmacol., 49: 314-318.

Sonavane, G.S., Sarveiya, V.P., Kasture, V.S., Kasturi, S.P. 2002. Anxiogenic activity of Myristica fragrans seeds. Pharmacol. Biochem. Behav., 71: 239-244.

Zick, S.M., Djuric, Z., Ruffin, M.T., Litzinger, A.J., Normolle, D.P., Alrawi, S., Feng, M.R., Brenner, D.E. 2008. Pharmacokinetics of 6-gingerol, 8-gingerol, 10-gingerol, and 6shogaol and conjugate metabolites in healthy human subjects. Cancer Epidemiol. Biomarkers Prev., 17: 1930-1936.

\section{How to cite this article:}

Samuel N. Osei-Djarbeng, Amina Abubakari, Charles Ayensu Okai, Ruth Boateng and George A. Pesewu. 2016. Antimicrobial Potential of Some Local Spices Used in Ghanaian Meals. Int.J.Curr.Microbiol.App.Sci. 5(5): 692-700. doi: http://dx.doi.org/10.20546/ijcmas.2016.505.070 